\title{
The relationship between neutrophil-to-lymphocyte ratio and platelet-to-lymphocyte ratio in patients with obstructive sleep apnea syndrome
}

\author{
Obstruktif uyku apne sendromunda platelet lenfosit oranı ve nötrofil lenfosit oranı ilişsisi
}

\author{
Hülya Günbatar1, Selami Ekin¹, Aysel Sünnetçioğlu ${ }^{1}$, Ahmet Arısoy¹, Buket Mermit Çilingir², Selvi \\ Aşker $^{1}$, Bünyamin Sertoğullarından ${ }^{1}$
}

\begin{abstract}
Objective: There is a strong relationship between obstructive sleep apnea syndrome (OSAS) and cardiovascular disease (CVD). Chronic intermittent hypoxia, inflammation, oxidative stress, and endothelial dysfunction may create etiologic mechanisms, connection between OSAS to CVD. Inflammation play an important role in the development of CVD. Platelet- Lymphocyte Ratio (PLR) and Neutrophil-lymphocyte Ratio (NLR) are new biomarkers showing inflammation. This study was designed to investigate the association between PLR, NLR and relationship between severity of OSAS, polysomnographic parameters and PLR.
\end{abstract}

Methods: This was a cohort study in which patients who had undergone a full night polysomnography for diagnosis of OSA were recruited. Patients were divided according to their apnea hypopnea index (AHI) scores into OSAS negative simple snoring (Group 1; $\mathrm{AHI}<5$ times/hours), mild (Group 2; AHI: 5-15), moderate (Group 3; AHI:15-30), and severe OSAS (Group 4; $\mathrm{AHI}>30$ ) groups.

Results: A total of 111 patients were included in this study. There were 26, 22 and 63 patients in Groups 1, 2 and 3 , respectively. PLR were significantly different between groups (Group 1: 87.12, Group 2: 103.6, Group 3: 112.5, $p<0.05)$. PLR were significantly correlated with $\mathrm{NLR}, \mathrm{AHI}$, oxygen desaturation index, average and minimum $\mathrm{O} 2$ saturation values $(p<0.05)$. Multiple regression analysis demonstrated that PLR is an independent predictor of CVD. PLR cut-off value for demonstrating the presence of CVD is higher than 86.03.

Conclusion: In the light of these findings, PLR is strongly associated with the severity of OSAS. PLR might be used as a biomarker to predict CVD in OSAS patients.

Key words: obstructive sleep apnea, inflammation, platelet to lymphocyte ratio

\section{ÖZET}

Amaç: Obstruktif Uyku Apne Sendromu (OSAS) ile Kardiyovasküler Hastalıklar (KVH) arasında güçlü bir ilişki vardır. Kronik intermittan hipoksi, inflamasyon, oksidatif stres ve endotelyal disfonksiyon OSAS ve KVH arasındaki etyolojik mekanizmaları ortaya çıkarmış olabilir. İnflamasyon KVH gelişiminde önemli rol oynar. Platelet Lenfosit Oranı (PLO) ve Nötrofil Lenfosit Oranı (NLO) inflamasyonu gösteren yeni belirteçlerdir. Bu çalışma PLO ve NLO arasındaki ilişkiyi ve OSAS şiddeti, polisomnografik parametreler ve PLR arasındaki ilişkiyi araştırmaktadır.

Yöntemler: OSAS ön tanısı ile tüm gece polisomnografisi yapılan hastaların çalışmaya dahil edildiği bir kohort çalışması planlandı. Hastalar apne hipopne indeksi skorlarına göre sınıflandırıldı. Basit horlama (Grup 1; AHI <5 adet/ saat), hafif OSAS (Grup 2; AHI: 5-15), orta derece OSAS (Grup 3; AHI: 15-30) ve ağrı OSAS (Grup 4; AHI >30).

Bulgular: 111 hasta çalışmaya dahil edildi. Grup 1, 2 ve 3 'te sırasıyla 26, 22 ve 63 hasta vardı. PLO gruplar arasında anlamlı düzeyde değişiklik göstermekteydi. Grup 1'de 87,12, Grup2'de 103,6, Grup 3'te 112,5 idi ( $p<0.05$ ). PLO ile NLO, AHI, oksijen desaturasyon indeksi, ortalama ve minimum oksijen saturasyon değeri arasında anlamlı derecede ilişki vardı $(p<0.05)$. Çoklu regresyon analizi ile PLO' nun KVH için bağımsız bir belirleyici olduğu saptandı. KVH varlığında, PLO cut off değerinin 86,03 olduğu gösterildi.

Sonuç: Tüm bu bulgular ışığında PLO ile OSAS şiddeti arasında güçlü ilişki vardır. PLO OSAS hastalarında KVH varlığını belirlemede bir belirteç olarak kullanılabilir.

Anahtar kelimeler: obstruktif uyku apnesi, inflamasyon, platelet lenfosit oranı

\footnotetext{
${ }^{l}$ Yüzüncü Yıl Üniversitesi Dursun Odabaşı Tıp Merkezi Gögüs Hastalıklarl, Van, Türkiye

${ }^{2}$ Van Bölge Eğitim ve Araştırma Hastanesi Göğüs Hastalıklarl, Van, Türkiye
}

Yazışma Adresi /Correspondence: Buket Mermit Çilingir,

Van Bölge Eğitim ve Araştırma Hastanesi Gögüs Hastalıkları Bölümü, Van, Türkiye Email: buketmermitcilingir@gmail.com Geliş Tarihi / Received: 15.05.2015, Kabul Tarihi / Accepted: 30.07.2015

Copyright @ Dicle Tıp Dergisi 2015, Her hakkı saklıdır / All rights reserved 


\section{INTRODUCTION}

Obstructive sleep apnea syndrome (OSAS) is characterized by collapse of the upper airway during sleep, recurring apnea, intermittent hypoxemia, and daytime sleepiness, associated with a decreased daytime performance and impaired quality of life [1]. It is a common disorder of middle-aged adults, affecting $4 \%$ of men and $2 \%$ of women [2].

Recent studies have indicated that OSAS is associated with multiple causal factors of endothelial damage and atherosclerosis due to oxidative stress, systemic inflammation and increased levels of soluble adhesion molecules and coagulation factors $[3,4]$. One routinely available marker of the systemic inflammatory response is the neutrophillymphocyte ratio (NLR). The leukocyte count and its subtypes are well-known inflammatory markers $[5,6]$. Since the response to physiological stress of leukocytes in circulation leads to an increase in the number of neutrophils and a decrease in the number of lymphocytes, the ratio of these subgroups to each other is used as a marker of inflammation. During the inflammatory response, changes occur in the ratios of leukocyte subgroups in the circulation. Neutrophilia is accompanied by relative lymphopenia [7]. In recent years, neutrophilia and relative lymphocytopenia were shown to be an independent predictor of mortality in patients with acute heart failure $[4,8]$. As NLR, platelet-to-lymphocyte ratio (PLR) was found to associated with all cause mortality in patients with acute myocardial infarction. Thrombocytosis is caused by the stimulation of megakaryocytes by proinflammatory cytokines [9], and its association with prognosis shown in other related studies may be explained based on an elevated platelet count being an indicator of the severity of inflammation. However, to date, the data about PLR and its association with inflammation are lacking in OSAS patients. Therefore, we aimed to determine the relationship between PLR, NLR, and inflammation in OSAS patients.

\section{METHODS}

One hundred eleven patients between ages 27 and 69 who had undergone polysomnography examination at the sleep laboratory of the pulmonology department at the Faculty of Medicine at Yüzüncü
Y1l University Hospital between February 2014 and January 2014 were retrospectively evaluated. Polysomnography examinations at the sleep laboratory were conducted prior to inclusion in this study. $\mathrm{Pa}$ tients were excluded from the study if they had acute inflammation, infection, diabetes mellitus, systemic hypertension, hyperlipidemia, congestive heart failure, chronic renal failure, chronic liver disease, chronic obstructive pulmonary disease, connective tissue disease, or inflammatory bowel disease. According to the apnea hypopnea index (AHI), subjects were divided into three groups. Group 1 contained the control subjects without OSA (AHI $<5$ times/hours, $n=26$ ) Group 2 contained the patients with moderate OSA (AHI $=15-30$ times/hours, $n=$ 22 ), and Group 3 contained the patients with severe OSA (AHI $>30$ times/hours, $\mathrm{n}=63)$.

\section{Polysomnography}

Overnight polysomnography was performed with 16 channel Embla (Medcare Inc, Iceland) continuous sleep technician monitoring. The system consists of 4 channels of electroencephalogram (EEG) (with electrode placements at C4-A1, C3-A2, O2$\mathrm{A} 1$, and O1-A2), 2 channels of electrooculography (EOG), submental electromyography(EMG), oronasal air flow, thoracic and abdominal movements, pulse oximeter oxygen saturation, tibial EMG, body position detector, electrocardiogram and tracheal sound. Apnea was defined as the complete cessation of airflow lasting more than 10 seconds. Hypopnea was defined as a reduction $>30 \%$ in airflow lasting more than 10 seconds accompanied by $>4 \%$ desaturation and/or arousal. The average number of episodes of apnea and hypopnea per hour of sleep were measured as AHI. The OSAS diagnosis was made on the basis of an apnea/ hypopnea index (AHI) $>$ 5 times/hours. Sleep stages were scored following standard criteria with 30 -second epochs and were reviewed and verified by a certified sleep physician.

\section{Biochemical measurement}

Complete blood counts with automated differential counts, including leukocyte, neutrophil, and lymphocyte levels, were obtained the morning after the polysomnography. NLR was calculated by dividing the absolute neutrophil count by the absolute lymphocyte count. The hematological analysis was per- 
formed with a Coulter LH 750 hemogram device (Beckman Coulter, Fullerton, California).

\section{Statistical Analysis}

The results were explained as the mean \pm standard deviation. The parametric variables were compared using Student's t-test. The non-parametric continuous variables were compared with the MannWhitney U-test. Pairwise Pearson correlation was executed to estimate linear relationships between characteristics. All statistical calculations were performed using SAS version 9.3 (SAS, 2014). The results were considered statistically significant when the $\mathrm{p}$ value was $<0.05$.

\section{RESULTS}

A total of 111 patients examined by polysomnography were included in the analysis. The patients with OSA included 66 men (78.4\%) and 19 women (21.6\%). The OSA and control groups were similar in terms of sex and age ( $>>0.05)$. Clinical characteristics of the patients and controls are shown in Table 1 . There was no statistically significant difference between the two groups regarding the age, BMI, Epworth sleep score, there was no statistically significant difference on the gender distribution.

The mean AHI was $20.7 \pm 5.7$ in the moderate OSA group and $56.9 \pm 26.8$ in the severe OSA group. The difference in AHI and minimum oxygen desaturation between groups was statistically significant (Table 1). There was no significant statistical difference between NLR in the controls and patients with moderate and severe OSA but the NLR values were higher in patients with severe and moderate OSA than in the control group (respectively, $2.29 \pm 1.43$ and $1.95 \pm 0.93,1.73 \pm 0.68, p>0.05)$. The PLR values were statistically significant higher in patients with severe and moderate OSA than in the control group (respectively, $112.5 \pm 36.7$ and $103.69 \pm 39.1$, $87.1 \pm 21.3 \mathrm{p}=0.039$ ). Additionally, correlation of NLR and PLR with parameters of sleep was noted. NLR and PLR were positively correlated with BMI (NLR; $\mathrm{r}=0.540, \mathrm{p}<0.01$; PLR; $\mathrm{r}=0.514, \mathrm{p}<0.05$ ) and negatively correlated with oxygen desaturation time under $90 \%$ (NLR: $r=0.602, p<0.01$; PLR: $r=0.680$ $\mathrm{p}<0.01)$. PLR cut-off value for demonstrating the severity of OSAS is higher than 86.03. (sensitivity, $67.1 \%$ and specifity, $61.5 \%$ ) (Figure 1 ).

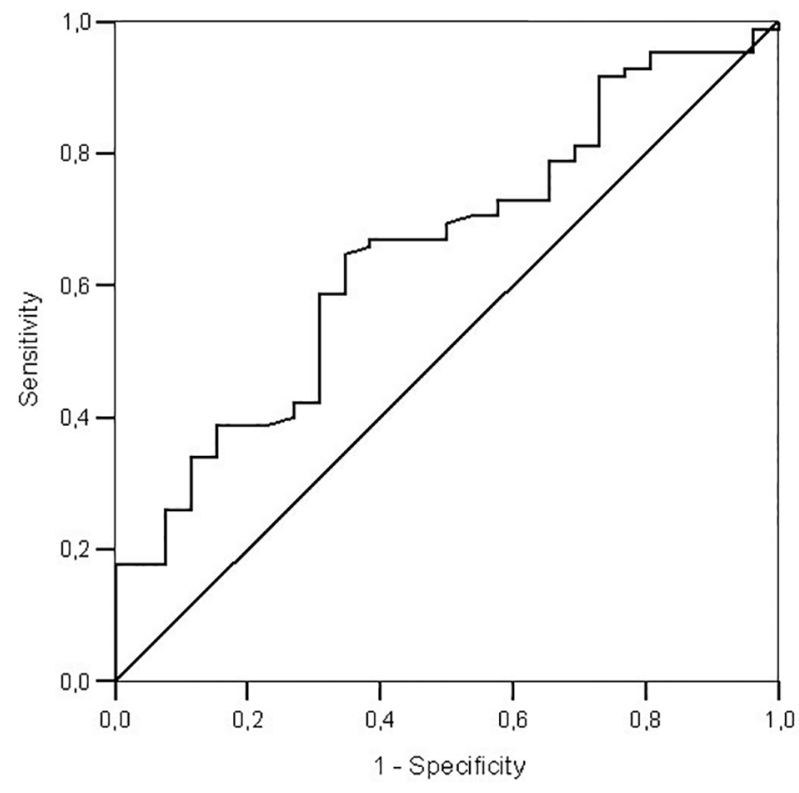

Figure 1. Roc curve for Platelet-to-Lymphocyte Ratio
Table 1. Anthropometric and polysomnographic features of obstructive sleep apnea patients and control group

\begin{tabular}{lcccc}
\hline Variables & Controls & $\begin{array}{c}\text { OSA } \\
\text { (Moderate) }\end{array}$ & $\begin{array}{c}\text { OSA } \\
\text { (Severe) }\end{array}$ & p \\
\hline Age(years) & $44,7 \pm 10,4$ & $49,3 \pm 10,6$ & $51,02 \pm 11,1$ & 0,050 \\
Gender(Male/female) & $21 / 5$ & $16 / 6$ & $50 / 13$ & 0,764 \\
BMI(kg/m²) & $27,15 \pm 5,0$ & $32,4 \pm 4,8$ & $33,5 \pm 5,9$ & 0,001 \\
AHI & $2,6 \pm 1,3$ & $20,7 \pm 5,7$ & $56,9 \pm 26,8$ & 0,001 \\
Lowest Saturation & $87 \pm 3,2$ & $73,7 \pm 12$ & $71,4 \pm 107$ & 0,001 \\
Desaturation time & $4,74 \pm 4,3$ & $62,8 \pm 43,7$ & $88,5 \pm 67$ & 0,001 \\
NLR & $1,73 \pm 0,68$ & $1,95 \pm 0,9$ & $2,29 \pm 1,4$ & 0,164 \\
PLR & $87,1 \pm 21,3$ & $103,69 \pm 39,1$ & $112,5 \pm 36,7$ & 0,039 \\
\hline
\end{tabular}

BMI: Body mass index, AHI: Apnea-hypopnea index, NLR: Neutrophil-lymphocyte ratio, PLR: Platelet-to-lymphocyte ratio 


\section{DISCUSSION}

There were two main findings of the present study. First, inflammation markers including PLR, NLR, were increased in OSA patients when compared with simple snoring patients. Second, PLR was positively correlated with NLR, and PLR were significantly correlated with AHI, oxygen desaturation index, average and minimum $\mathrm{O}_{2}$ saturation values $(\mathrm{p}<0.05)$.

The NLR was introduced as a cost-effective potential inflammatory marker with prognostic and predictive values in systemic inflammatory diseases such as cardiovascular disease, kidney disease, inflammatory bowel disease, and familial Mediterranean fever [10-14]. In many studies, white blood cell counts and their subtypes have been found to be classic inflammatory markers, especially in cardiovascular disease $[15,16]$. OSA is not a simple respiratory abnormality that occurs during sleep; the systemic inflammatory response generated by OSA can be associated with cardiovascular disease and considered a new, independent cardiovascular risk factor [17,18]. Various studies have demonstrated elevated inflammatory marker levels in OSA patients compared with matched controls, with a significant fall after effective treatment with continuous positive airway pressure [19]. Intermittent hypoxia and sleep deprivation may explain the relationship between inflammatory markers and AHI in OSA and is a trigger for the cardiovascular and metabolic alterations. Many studies have reported that patients with OSA develop systemic inflammation, with increased levels of mediators of the systemic inflammatory response, including intercellular adhesion molecules (ICAM), coagulation factors (Factor VIII, tissue factor), and C-reactive protein (CRP) [20-22]. In this study, increased NLR could be a new inflammatory marker for inflammation in OSA patients. Furthermore, NLR might also be influenced by many different factors, including atherosclerosis, hypertension, and diabetes, and can even be affected by atherosclerotic risk factors [23]. In this study, our patient population was free of conditions that increase NLR, such as cardiovascular disease, hypertension, hypercholesterolemia, and diabetes mellitus.
As new inflammation markers, PLR and NLR were introduced in cardiac and noncardiac disorders [24]. Recent studies demonstrated that activated platelets could be an important part of increased atherogenesis especially in the period of inflammation $[25,26]$. Platelets can interact with a kind of different cell types including endothelial cells, dendritic cells, T-lymphocytes, neutrophils, and mono-nuclear phagocytes, the relationship of platelets with these cells mentioned above might initiate and exacerbate the inflammation in the arterial wall. There has been an increasing evidence demonstrated that activated platelets could incite leukocyte recruitment to the vessel wall and initiate the inflammation that can mainly seen in the pathogenesis of atherosclerosis [27].

This study demonstrates a relationship between the severity of OSA and PLR that is dependent on inflammation and intermittent hypoxia. PLR was significantly increased in patients with moderate to severe OSA compared to patients with no OSA. Only one study have suggested the optimal cut-off value for PLR at $>108.6$ in OSAS patients for cardiovascular risk factors (28). Multiple regression analysis demonstrated that PLR is an independent predictor of CVD. In this study PLR cut-off value for demonstrating the presence of CVD is higher than 86.03. PLR could be considered a new inflammatory marker for inflammation in OSA patients.

This study also found a positive association between NLR, PLR and the lowest oxygen desaturation time and desaturation time under $90 \%$ in OSA, which could be explained by the effect of hypoxia on NLR and PLR.

Calculation of PLR and NLR are quite simple and inexpensive methods when compared other inflammatory cytokines including IL-6, IL-1b, and TNF-a. Our results confirm that PLR and NLR can predict inflammation in OSAS patients. Therefore, these simple, relatively cheap and universally available methods can be used by clinicians for the first assessment of inflammation in OSAS patients before applying other expensive and invasive procedures.

This study had some limitations. First, the study population was relatively small. Second, inflamma- 
tory markers such as CRP and fibrinogen were not analyzed and compared with NLR and PLR in the study population.

In conclusion, novel biomarkers are needed to indicate the level inflammation of disease in patients with OSA. Therefore, PLR could be considered a new inflammatory marker for inflammation in OSA patients, as it is a quick, cheap, and easily measurable property on routine $\mathrm{CBC}$ analysis.

\section{REFERENCES}

1. Young T, Palta M, Dempsey J, et al. The occurrence of sleepdisordered breathing among middle- aged adults. N Engl J Med 1993;328:1230-1235.

2. Lattimore JD, Celermajer DS, Wilcox I. Obstructive sleep apnea and cardiovascular disease. J Am Coll Cardiol 2003;41:1429-1437.

3. Ryan S, Taylor CT, McNicholas WT. Systemic inflammation: a key factor in the pathogenesis of cardiovascular complications in obstructive sleep apnoea syndrome? Thorax 2009;64:631-636.

4. Yokoe T, Minoguchi K, Matsuo H, et al. Elevated levels of Creactive protein and interleukin- 6 in patients with obstructive sleep apnea syndrome are decreased by nasal continuous positive airway pressure. Circulation 2003;107:11291134.

5. Thomsen M, Ingebrigtsen TS, Marott JL, et al. Inflammatory biomarkers and exacerbations in chronic obstructive pulmonary disease. JAMA 2013;309:2353-2361.

6. Hotchkiss RS, Karl IE. The pathophysiology and treatment of sepsis. NEJM 2003;348:138-150.

7. Mehta J, Dinerman J, Mehta P, et al. Neutrophil function in ischemic heart disease. Circulation 1989;79:549-546.

8. Rudiger A, Burckhardt OA, Harpes $\mathrm{P}$, et al. The relative lymphocyte count on hospital admission is a risk factor for long-term mortality in patients with acute heart failure. Am J Emerg Med. 2006;24:451-454.

9. Alexandrakis MG, Passam FH, Moschandrea IA, et al. Levels of serum cytokines and acute phase proteins in patients with essential and cancer-related thrombocytosis. Am J Clin Oncol 2003; 26:135-140.

10. Ahsen A, Ulu MS, Yuksel S, et al. As a new inflammatory marker for familial Mediterranean fever: Neutrophil-tolymphocyte ratio. Inflammation. 2013;36:1357-1362.

11. Núñez J, Núñez E, Bodí V, et al. Usefulness of the neutrophil to lymphocyte ratio in predicting long-term mortality in ST segment elevation myocardial infarction. Am J Cardiol 2008;101:747-752.

12. Ertaş G, Sönmez O, Turfan M, et al. Neutrophil/lymphocyte ratio is associated with thromboembolic stroke in patients with non-valvular atrial fibrillation. J Neurol Sci 2013;324:49-52.
13. Celikbilek M, Dogan S, Ozbakir O, et al. Neutrophil-lymphocyte ratio as a predictor of disease severity in ulcerative colitis. J Clin Lab Analysis 2013;27:72-76.

14. Okyay GU, Inal S, Oneç K, et al. Neutrophil to lymphocyte ratio in evaluation of inflammation in patients with chronic kidney disease. Renal Failure 2013;35:29-36.

15. Akpek M, Kaya MG, Lam YY, et al. Relation of neutrophil/ lymphocyte ratio to coronary flow to in-hospital major adverse cardiac events in patients with ST-elevated myocardial infarction undergoing primary coronary intervention. Am J Cardiol 2012;110:621-627.

16. Gibson PH, Cuthbertson BH, Croal BL, et al. Usefulness of neutrophil/lymphocyte ratio as predictor of new-onset atrial fibrillation after coronary artery bypass grafting. Am J Cardiol 2010;105:186-191.

17. Pack AI, Gislason T. Obstructive sleep apnea and cardiovascular disease: a perspective and future directions. Prog Cardiovasc Dis 2009;51:434-451.

18. Horne BD, Anderson JL, John JM, et al. Which white blood cell subtypes predict increased cardiovascular risk? J Am Coll Cardiol 2005;45:1638-1643.

19. Kent BD, Ryan S, McNicholas WT. Obstructive sleep apnea and inflammation: Relationship to cardiovascular comorbidity. Respir Physiol Neurobiol 2011;178:475-481.

20. Yokoe T, Minoguchi K, Matsuo H, et al. Elevated levels of C-reactive protein and interleukin-6 in patients with obstructive sleep apnea syndrome are decreased by nasal continuous positive airway pressure. Circulation. 2003;107:1129-1134.

21. Shamsuzzaman AS, Winnicki M, Lanfranchi P, et al. Elevated C-reactive protein in patients with obstructive sleep apnea. Circulation 2002;105:2462-2464.

22. Kokturk O, Ciftci TU, Mollarecep E, et al. Elevated C-reactive protein levels and increased cardiovascular risk in patients with obstructive sleep apnea syndrome. Int Heart J 2005;46:801-809.

23. Szkandera J, Pichler M, Gerger A, et al (2013b) Reply: comment on 'Elevated preoperative neutrophil/lymphocyte ratio is associated with poor prognosis in soft-tissue sarcoma patients'. Br J Cancer 108:2627.

24. Dotsenko O, Chaturvedi N, Thom SA, et al. Platelet and leukocyte activation, atherosclerosis and inflammation in European and South Asian men.J Thromb Haemost 2007;5:2036-2042.

25. Koyama H, Maeno T, Fukumoto S, et al. Platelet P-selectin expression is associated with atherosclerotic wall thickness in carotid artery in humans. Circulation 2003;108:524-529.

26. Shoji T, Koyama H, Fukumoto S, et al. Platelet activation is associated with hypoadiponectinemia and carotid atherosclerosis. Atherosclerosis 2006;188:190-195.

27. Langer HF, Gawaz M. Platelet-vessel wall interactions in atherosclerotic disease. Thromb Haemost 2008;99:480 486.

28. Koseoglu HI, Altunkas F, Kanbay A, et al. Platelet-lymphocyte ratio is an independent predictor for cardiovascular disease in obstructive sleep apnea syndrome. J Thromb Thrombolysis 2015;39:179-185. 